\title{
THE SALIENT POINTS IN THE GERMAN CONSTITUTION OF I9I9
}

\begin{abstract}
$7 \mathrm{TE}$ German Constitution of IgI9 is the production of the right wing of those belonging to the party known as the Social Democrats, and until the fall of the empire commonly called the International Socialist Party.
\end{abstract}

\section{THE FRAMING OF TEE CONSTITUTION}

The revolution became an accomplished fact on November 9, I9I8, two days before the armistice. The left wing desired to use the opportunity to put the main features of Socialism immediately into the form of law. The leading figure in German politics then, as now, was Frederick Ebert. He succeeded, or assumed to succeed, Prince Maximilian as Chancellor on November 9, under a provisional scheme of administration which contemplated the early establishment of a regular constitutional government. A "Council of People's Commissioners" having been organized, Ebert assumed its chairmanship, and on November 30,1918 , issued by authority of the Council an order for the assemblage of a Constitutional Convention. As no such body had existed under the empire, it was necessary, in calling it, to define who should vote for its members. The occasion invited such regulations as would harmonize with the spirit of the revolution, and the order provided for election by universal suffrage, irrespective of sex, and proportional representation. Of the 423 delegates whom the people chose, 37 were women.

The elections were held on January 19, I9I9, and the Convention met at Weimar on February 6 . On February to it recognized and, with slight changes, confirmed the existing provisional government. Later in the month a draft of a permanent Constitution was introduced. Discussions of the project and of amendments to it that had been proposed began promptly, and were continued in a special commission, organized for the purpose, in March, May and June. A permanent Constitution, in a form approved by the commission, was discussed in the Convention through July, and on July 3 I, with a few alterations, was finally adopted by the votes of a very large majority of the delegates. It was therefore not hastily constructed. The Convention worked on it, by itself and its commission, during half a year,-a month longer than the time spent on a similar undertaking by our Constitutional Convention of 1787 at Philadelphia. 
THE CONSTITUTYON NOT SUBMITTED TO THE PEOPLE

There was no referendum to the people. The Constitution went into force (Article I8I) on August II, I9I9, when it was promulgated by the newly-elected President of the German Commonwealth and the Cabinet. The taking effect of a few provisions was deferred till later periods.

This omission of a requirement of a referendum was in accordance with long-established principles of German practice. During the existence of the empire no imperial statute became of force until promulgated by the emperor. The form pursued was to prefix to it a certificate that "We, William, by the grace "of God German emperor, etc., *** order in the name of the empire, pursuant to the assent of the Bundesrat and the Reichstag, what follows." Then followed the text of the statute and, after that, the attestation clause, with the place and date of promulgation, signed by the emperor and the chancellor. It was he who spoke in the name of the empire: it was his issuance that gave it force.

The Constitution of I9r9 (Article 76) says distinctly that it may be amended by process of legislation. A two-thirds vote of those present when the vote of the Reichstag is taken is required, and they must also be two-thirds of its entire legal membership. A two-thirds vote of all present in the upper house or "Reichsrat," in acting on such a question, is also necessary. If the two houses do not agree, the Reichsrat may require a referendum. It has a similar power in certain other cases: 'There can be no amendment of the Constitution by a popular referendum unless by a vote of a majority of the qualified voters, whether voting or not voting.

\section{RELATION OF THE NATION TO THE STATES}

The Constitution of I87I, by its heading, purported to form an "eternal union" of the several states "for the protection of the realm and the care of the welfare of the German people." The heading of the Constitution of I9I9 asserts that "the German people, united in all their branches and inspired by the determination to renew and strengthen their domain in liberty and justice, to preserve peace, both at home and abroad, and to foster social progress, has adopted the following Constitution." The Treaty of Peace was signed for Germany by two of the ministers of the Ebert government at that time, describing themselves as "acting in the name of the German empire and in the name of all the states which compose it, and each of them in particular." Here is a flashlight pic- 
ture of the German situation when the draft of the Peace Treaty was adopted by the allied and associated powers. It could be claimed on its face to be with a single political sovereign-the empire of the German people as a whole; or as a confederation of the component states; or as a combination of some of them. The Constitution of I9I9 is a choice between these alternatives. It begins with the explicit statement that it is the work of "the German people" united "in all their branches." "Branches" can hardly mean anything but "States." Article I confirms this construction by the affirmation that "political authority is derived from the people," and Article 5 tells us that "it is exercised in national affairs by the National Government in accordance with the Constitution of the Commonwealth, and in State affairs by the State Governments in accordance with the State Constitutions." The strongest of sanctions for this scheme of division is prescribed in Article 48, which provides that "If any State does not perform the duties imposed upon it by the Constitution or by national laws, the National President may hold it to the performance thereof by force of arms." Here, of course, is a repudiation of anything like the American doctrine, or what remains of the American doctrine, of "States Rights." Under our Constitution, if a State takes action, through those in charge of its government, hostile to the government of the United States, individuals by whom such action is taken may be proceeded against by the United States, and can take no benefit from any State authority which they may claim. Texas v. White, 7 Wall. 700. Such authority does not exist, in legal effect. Under the German Constitution the State authority may apparently be regarded as an important factor in the transaction. The State is the sinner, and must answer for its wrongs, like any other wrongdoer. It can, as a State, be subjected to a military attack by the forces of the nation. It is applying the principle of ordering a "specific performance."

The questions which have arisen under the Eighteenth Amendment to the Constitution of the United States as to the concurrent powers of 'State and nation are avoided by a provision that "the laws of the Commonwealth are supreme over the laws of the States which conflict with them. If doubt arises, or differences of opinion, whether State legislation is in harmony with the law of the Commonwealth, the proper authorities of the Commonwealth or the central authorities of the States, in accordance with specific provisions of a national law, may have recourse to the decision of a supreme judicial court of the Commonwealth" (Article 13). 
It is made the duty of the State authorities to execute the laws of the Commonwealth, except in cases where the latter provide otherwise (Article 24). The national cabinet may issue instructions to the States as to their exercise of such powers, and may send commissioners to each to supervise its action in such matters (Article I5).

The whole frame of the Constitution is a sign of the general unwillingness of modern society to divide, and thereby weaken, national sovereignty. In former times, if a confederation of nations was formed, each of the component powers was allowed to retain a large share of what had been its previous authority over its subjects or citizens. The first Constitution of the United States (the Articles of Confederation) left each State, in almost everything, its own master; and therefore it failed. The second Constitution, under which we now live, originally represented, in a considerable degree, the other school of thought. It left the internal sovereignty of the several States but slightly impaired. The "Ideas of '89," under the influence of which it was devised, were mainly conversant with the relations of the State to the individual. The sovereign people dealt directly with each of themselves. Each man was guaranteed certain rights against any action which the people of the United States could take. Each State was, likewise, in most things autonomous as regards the nation; and, as a State, supreme as to its own citizens. As time has gone on important limitations of State sovereignty have been introduced. Beginning with the Thirteenth Amendment of the Constitution of the United States, it has been so altered as in many things to tie the hands of the States which were free before. They cannot forbid the negro to vote; they cannot choose their Senators by votes of their legislators; their people cannot drink the lightest wine; they probably cannot long deny to women every privilege to vote which they give to men.

Germany has now departed from the theory under which her Constitution of $187 \mathrm{I}$ was framed, and ranged herself on the side of those who, as far as possible, would keep sovereignty undivided. Indeed, she has gone much further, by allowing the nation to reconstitute or even wholly destroy a State without its consent. Article I8 provides on this subject that "the division of the Commonwealth into States shall serve the highest economic and cultural interests of the people after most thorough consideration of the wishes of the population affected. State boundaries may be altered and new States may be created within the Commonwealth by the 
process of constitutional amendment. With the consent of the States directly affected, it requires only an ordinary law of the Commonwealth. An ordinary law of the Commonwealth will also suffice, if one of the States affected does not consent, provided that the change of boundaries or the creation of a new States is desired by the population concerned and is also required by a preponderant national interest."

\section{INTERNATIONAL IAẌ}

International law was recognized as a part of the laws of the United States by the provision in our Constitution (Article I, Section 8) that Congress shall have power to define and punish "offenses against the Law of Nations." U. S. v. Arjona, 20 U. S. 479. No nation had previously gone so far. The German Constitution goes much father by declaring (Article 4) that "the generally recognized principles of the law of nations are accepted as an integral part of the law of the German Commonwealth." Here we have a definition of what of those principles are recognized as obligatory throughout the Commonwealth. They are those which are "generally recognized." It would have been to order the impossible to specify them in detail in such an instrument.

Article 148 , if its directions are intelligently carried out, will make the task of definition easier for coming generations. It begins thus :

"All schools shall inculcate moral education, civic sentiment, and personal and vocational efficiency in the spirit of German national culture and of international conciliation.

"The National President represents the Commonwealth in matters of international law. He concludes in the name of the Commonwealth alliances and other treaties with foreign powers. He accredits and receives ambassadors.

"War is declared and peace concluded by national law.

"Alliances and treaties with foreign States, relating to subjects within the jurisdiction of the Commonwealth, require the consent of the Reichstag" (Article 45).

\section{THE NATIONAL PRESIDENT}

The President holds for a seven-year term, and is eligible for reelection. He is, however, removable on the proposal of the Reichstag by a two-thirds vote, approved by a vote of the people. 
"A refusal by the people to remove the President has the effect of a new election and entails the dissolution of the National Assembly" (Article 43).

$\mathrm{He}$ is the supreme military commander; and appoints and dismisses the civil and military officers of the Commonwealth, if not otherwise provided by law (Article 46 ). This would seem to imply that the Reichstag could abridge or revoke this power in these respects.

"If public safety and order in the German Commonwealth is materially disturbed or endangered, the National President may take the necessary measures to restore public safety and order, and, if necessary, to intervene, by force of arms."

Like authority is given to the State cabinets, in case of local disturbances, if there is danger from delay (Article 48).

"All orders and directions of the National President, including those concerning the armed forces, require for their validity the countersignature of the National Chancellor or of the appropriate National Minister. By the countersignature responsibility is assumed" (Article 50).

The President's position is one largely of dignity and ceremonial.

"The National Chancellor and the National Ministers require for the administration of their offices the confidence of the Reichstag. Each of them must resign if that body by formal resolution withdraws its confidence.

"The National Chancellor presides over the National Cabinet and conducts its affairs in accordance with rules of procedure, which will be framed by the National Cabinet and approved by the National President.

"The National Chancellor determines the general course of policy and assumes responsibility therefor to the Reichstag. In accordance with this general policy each National Minister conducts independently the particular affairs intrusted to him and is held individually responsible to the Reichstag" (Articles 54, 55, 56).

TEE REICHSTAG

Contested elections to the Reichstag are to be decided by a mixed Commission, composed of some of its members and some of the Judges of a "National Administrative Court," who are appointed by the President of the Commonwealth on the nomination of the President of this Court. Of this Commission, five constitute a quo- 
rum, provided three be members of the Reichstag and two Judges of the Court. This Commission also has jurisdiction to decide whether, in any case, a member has forfeited his seat (Article $3 I$ ).

The National Ministers have the right to be present and be heard at the meetings of the Reichstag or any of its committees. So have representatives of the State cabinets (Article 33).

Two standing committees of the Reichstag have large powers when it is not in session. One is a committee on foreign affairs; another is "for the protection of the rights of the representatives of the people against the National Cabinet during a recess and after the expiration of the term for which it was elected" (Article 35).

The Reichstag has the sole power of legislation, except in case of a referendum to the people (Article 68). The National Cabinet can introduce bills with the assent of the Reichsrat. If that body refuses consent, the cabinet may introduce it, but only with mention of the dissent of the Reichsrat. So if the Reichsrat resolves on a bill to which the National Cabinet does not assent, the cabinet may introduce it, with mention of the dissent (Article 69).

National laws do not go into effect until they have been officially promulgated by the President of the Commonwealth, nor until the fourteenth day after their publication in the National Bulletin of Laws at the capital (Article $7 \mathrm{r}$ ). The promulgation may be deferred for two months, if one-third of the Reichstag so demand, provided that if both Houses declare a certain law to be urgent, the President may promulgate it without compliance with such a demand (Article 72).

Any law shall be referred to the people, before its promulgation, if the National President so orders within a month.

A law whose promulgation is deferred at the demand of at least one-third of the Reichstag shall be submitted to the people, if onetwentieth of the qualified voters so petition.

A popular vote shall further be resorted to on a measure initiated by the people if one-tenth of the qualified voters so petition. A fully elaborated bill must accompany such petition. The National Cabinet shall lay the bill, with a statement of its attitude, before the Reichstag. The popular vote does not take place if the desired bill is enacted without amendment by the Reichstag (Article 73).

The Reichsrat may demand the reconsideration of any enactment. If the two Houses still cannot agree, the National President may within three months refer the subject of the dispute to the people. If the President makes no use of this right, the law does 
not go into effect. If the Reichstag disapproves by a two-thirds majority the objection of the Reichsrat, the President shall promulgate the law in the form enacted by the Reichstag within three months or refer it to the people (Article 74).

\section{THE REICHSRAT}

An upper house of legislation (the Bundesrat of the former Constitution) is replaced by a Reichsrat or National Council. In this each of the States has at least one vote, and an additional vote for every million inhabitants, except that in no case can a State (meaning evidently Prussia) have more than two-fifths of all votes (Article 6I).

The powers of the Reichsrat are less than those possessed by the old Bundesrat. The authority and jurisdiction of the States being lessened as those of the people are increased, it became of less importance what the Council of the States might do or not do.

\section{COURTS}

The present system is continued, under which all ordinary jurisdiction will be exercised by the National Judicial Court and the Courts of the States (Articles ro3, I08).

Judges are appointed for life (Article I04).

There are to be administrative courts both in the Commonwealth and in the States, in acordance with the laws, to protect the individual against orders and decrees of administrative authorities.

Under the former Constitution, methods of judicial procedure in all actions were to be uniform, and determined by national law. No change is made in this respect, nor as to giving an appeal from State Courts to the National Judicial Court, without any limitations as to the subject matter of the suit or the citizenship of the parties. ${ }^{1}$

"If controversies concerning the Constitution arise within a State in which there is no court competent to dispose of them, or if controversies of a public nature arise between different States or between a State and the Commonwealth, they will be determined upon complaint of one of the parties by the Supreme Judicial Court of the German Commonwealth, unless another judicial court of the Commonwealth is competent.

'See "A German Law Suit" Ig Yale Lnw Jour. 69, and "The German Law Suit without a Lawyer," 8 Mich. L. Rev. 30. 
"The President of the Commonwealth executes judgments of the Supreme Judicial Court."

\section{PERSONAL AND SOCIAL, RIGHTS}

Although the Communists and the more radical Socialists obtained much less than they sought at the hands of the Weimar Convention, the Socialistic character of the Constitution stands out prominently.

It begins with announcing that one of its main objects is to "foster social progress."

The Commonwealth (Article 7 ) has concurrent jurisdiction over "the rights of labor, social insurance, and protection of wageearners and other employees, and employment bureaus." Whenever (Article 9) it is necessary to establish uniform rules, the Commonwealth has jurisdiction over: I. The promotion of social welfare; 2. The promotion of public order and safety. Whether or not it is necessary to establish such rules, it has jurisdiction, among other things, over (Article 7) "the establishment of national organizations for vocational representation," and "the socialization of natural resources and business enterprises, as well as the production, fabrication, distribution, and price-fixing of economic goods for the use of the community."

So far as any of the specific grants of concurrent jurisdiction contained in Article 7 are left unused by the Commonwealth, the States will retain their jurisdiction over them, but with a saving to the National Cabinet of the right to object to State laws on these subjects, "whenever the general welfare of the Commonwealth is affected thereby" (Article I2).

It is provided that "the regulation of economic life must conform to the principles of justice, with the object of assuring humane conditions of life for all. Within these limits the economic liberty of the individual shall be protected. Legal compulsion is permissible only for safeguarding threatened rights or in the service of predominant requirements of the common welfare" (Article I5I). "Freedom of contract prevails in economic relations in accordance with the laws" (Article r52).

"The right of private property is guaranteed by the Constitution. Its nature and limits are defined by law. Expropriation may be proceeded with only for the benefit of the community and by due process of law. There shall be just compensation in so far as not otherwise provided by national 
law." *** Property-rights imply property-duties. Exercise thereof shall at the same time serve the general welfare" (Article I53).

"The distribution and use of the land is supervised by the State in such a way as to prevent its misuse and to promote the object of insuring to every German a healthful dwelling and to all German families, especially those with numerous children, homesteads corresponding to their needs. *** The cultivation and utilization of the soil is a duty of the landowner toward the community. An increase of the value of land arising without the application of labor or capital to the property shall inure to the benefit of the community as a whole" (Article I55).

The most radical of any of the principles established by the Constitution is found in Article 156.

"The Commonwealth may by law, without impairment of the right to compensation, and with a proper application of the regulations relating to expropriation, transfer to public ownership private business enterprises adapted for socialization. The Commonwealth itself, the States, or the municipalities may take part in the management of business enterprises and associations, or secure a dominating influence therein in any other way.

"Furthermore, in case of urgent necessity, the Commonwealth, if it is in the interest of collectivism, may combine by law business enterprises and associations on the basis of administrative autonomy, in order to secure the coöperation of all producing elements of the people, to give to employers and employees a share in the managenent, and to regulate the production, preparation, distribution, utilization and pecuniary valuation, as well as the import and export, of economic goods upon collectivistic principles.

"The coöperative societies of producers and of consumers and associations thereof shall be incorporated, at their request and after consideration of their form of organization and peculiarities, into the system of collectivism."

A uniform labor law is also guaranteed, and the policy is announced of "an international regulation of the legal status of the workers, which shall strive for a standard minimum of social rights for the whole working class of the world" (Articles I57, I59, I62). Trusts, trade combinations and trade unions are permitted. 
"The right of combination for the protection and promotion of labor and economic conditions is guaranteed to everybody and to all professions. Äll agreements and measures which attempt to limit or restrain this liberty are unlawful" (Article I59).

"Wage-earners and salaried employees are qualified to coöperate on equal terms with the employers in the regulation of wages and working conditions, as well as in the entire economic development of the productive forces. The organizations on both sides and the agreements between them will be recognized.

"The wage-earners and the salaried employees are entitled to be represented in local workers' councils, organized for each establishment in the locality, as well as in district workers' councils, organized for each economic area, and in a National Workers' Council, for the purpose of looking after their social and economic interests.

'The district workers' councils and the National Workers' Council meet together with the representatives of the employers and with other interested classes of people in district economic councils and in a National Economic Council for the purpose of performing joint economic tasks and coöperating in the execution of the laws of socialization. $* * *$ Drafts of laws of fundamental importance relating to social and economic policy before introduction" (into the Reichstag) "shall be submitted by the National Cabinet to the National Economic Council for consideration. The National Economic Council has the right itself to propose such measures for enactment into law. If the National Cabinet does not approve them, it shall, nevertheless, introduce them into the Reichstag, together with a statement of its own position. The National Economic Council may have its bill presented by one of its own members before the Reichstag" (Article r65).

The practice of supporting those for whom work cannot be found is to be continued (Article 163 ).

Individual rights are guarded in much the same way as in the United States Constitution.

One difference is the German assertion that "Men and women have fundamentally the same civil rights and duties" (Article rog). Another is that "No German may be surrendered to a foreign 
government for prosecution or punishment" (Article II2). This conforms to the general practice of Continental Europe.

A remedy analagous to the writ of habeas corpus is given by Article II4 in these terms:

"Persons who are deprived of their liberty shall be informed at latest on the following day by what authority and on what grounds they have been deprived of liberty, and they shall without delay receive an opportunity to present objections against such loss of liberty."

Freedom of expression, in matters of opinion, is thus protected by Article II8:

"Every German has a right within the limits of the general laws to express his opinion freely by word, in writing, in print, by picture, or in any other way. No relationship arising out of his employment may hinder him in the exercise of this right, and no one may discriminate against him if he makes use of this right."

"Previous notice may be required by national law for meetings in the open, and such meetings may be forbidden in case of immediate danger to the public safety" (Article I23).

Freedom of incorporation is thus guaranteed:

"All Germans have the right to form associations or societies for purposes not contrary to the criminal law. This right cannot be limited by preventive measures. The same provisions apply to religious associations and societies.

"Every association has the right of incorporation in accordance with the civil law. No association may be denied this right on the ground that it pursues a political, social-political, or religious object" (Article I24).

"Civil officers are appointed for life, in so far as is not otherwise provided by law. Pensions and provisions for surviving dependents will be regulated by law. The duly acquired rights of the civil officers are inviolable" (Article I29). "Freedom of political opinion and of association are assured" to them (Article I30).

\section{EDUCATTON}

Education is compulsory, and remains, in each State, under its immediate direction, but with the coöperation of the Commonwealth, which regulates the training of all teachers (Articles I43, I44, I45). 
"Religious instruction is included in the regular school curriculum, except in the non-sectarian (secular) schools. The imparting of religious instruction is regulated by the school laws. Religious instruction is imparted in accordance with the principles of the religious society concerned, without prejudice to the right of supervision of the State.

"The imparting of religious instruction and the use of ecclesiastical ceremonies is optional with the teachers, and the participation of the pupils in religious studies and in ecclesiastical ceremonies and festivities is left to the decision of those who have the right to control the religious education of the child.

"The theological faculties in the universities will be continued" (Article I49).

\section{WOMAN SUFFRAGE}

The success or failure of the Constitution must, of course, depend on whether it truly reflects the political opinions, of a majority of the German people. Goethe said, a hundred years ago, that all women are by nature conservative. If they, now fully part of the German electorate, should deem some of these new rules too radical, they may be able, with the aid of men of a similar opinion, to secure their ultimate abrogation, but it seems probable that for the next generation the Constitution of IgIg will remain, as to most points, the law of the land.

New Haven, Connecticut.

SIMEON E. BALDWIN. 